Table 3. Selected bond lengths $(\AA)$ and angles $\left(^{\circ}\right)$ for complexes of the type $\mathrm{Cl}_{2} \mathrm{Sn}\left[M L_{n}\right]_{2}$

\begin{tabular}{|c|c|c|c|c|c|}
\hline$M L_{n}$ & $\mathrm{Sn}-M^{*}$ & $\begin{array}{c}M-\mathrm{Sn}- \\
M^{*}\end{array}$ & $\mathrm{Sn}-\mathrm{Cl} *$ & $\underset{\mathrm{Cl}^{*}}{\mathrm{Cl}-\mathrm{Sn}-}$ & Ref. \\
\hline $\mathrm{Co}(\mathrm{CO})_{4}$ & $2 \cdot 534$ (1) & $129 \cdot 3(1)$ & $2.368(2)$ & $101 \cdot 3(1)$ & This work \\
\hline $\mathrm{Co}(\mathrm{CO})_{2}(\mathrm{nbd}) \dagger$ & $2 \cdot 498(1)$ & $128 \cdot 3(1)$ & $2 \cdot 410(2)$ & $98 \cdot 1(1)$ & (1) \\
\hline $\mathrm{Fe}(\mathrm{CO})_{2} \mathrm{Cp}$ & $2.492(8)$ & $128.6(3)$ & 2.43 (1) & $94 \cdot 1(6)$ & (2) \\
\hline $\mathrm{Mn}(\mathrm{CO})_{5}$ & $2.635(2)$ & $126 \cdot 2(1)$ & $2 \cdot 385(2)$ & $95.8(1)$ & (3) \\
\hline $\mathrm{Cr}(\mathrm{CO})_{3} \mathrm{Cp}$ & $2.697(2)$ & $130 \cdot 2(1)$ & $2.417(3)$ & $95 \cdot 0(1)$ & (4) \\
\hline
\end{tabular}

References: (1) Boer \& Flynn (1971); (2) O’Connor \& Corey (1967); (3) Preut, Wolfes \& Haupt (1975); (4) Stephens (1975).

* Average values.

$\dagger$ nbd $=$ norbornadiene.

the $\mathrm{Sn}-M$ bond going from $M=\mathrm{Cr} \rightarrow \mathrm{Mn} \rightarrow \mathrm{Co}$ as the atomic radius of the metal atom decreases across the series. The $\mathrm{Sn}-\mathrm{Fe}$ value for $\mathrm{Cl}_{2} \mathrm{Sn}\left[\mathrm{Fe}(\mathrm{CO})_{2} \mathrm{Cp}\right]_{2}$ (O'Connor \& Corey, 1967) appears smaller than expected from this trend, even allowing for the effect of the $\mathrm{Cp}$ ligand. Comparison of the $\mathrm{Sn}-\mathrm{Co}$ bond value for $\mathrm{Cl}_{2} \mathrm{Sn}\left[\mathrm{Co}(\mathrm{CO})_{4}\right]_{2}$ with that of the substituted $\mathrm{Cl}_{2} \mathrm{Sn}\left[\mathrm{Co}(\mathrm{CO})_{2}(\mathrm{nbd})\right]_{2} \quad(\mathrm{nbd}=$ norbornadiene) (Boer \& Flynn, 1971) shows that there is a significant contraction $[0.036(2) \AA]$ on replacing the CO ligand opposite the $\mathrm{Sn}-\mathrm{Co}$ bond by a $\eta^{2}-\mathrm{C}=\mathrm{C}$ group; this is yet another example of the relatively strong trans influence of a $\mathrm{CO}$ ligand in these complexes (Curnow, Nicholson \& Severinsen, 1990). For all of the examples given in Table 3 the $M-\mathrm{Sn}-M$ bond angles are much greater than the tetrahederal angle, but the overall range $\left(126 \cdot 3-130 \cdot 2^{\circ}\right)$ is surprisingly small considering the variation in steric properties of the $M L_{n}$ groups. This suggests an electronic rationale, with the Sn- $M$ bonds having enhanced $s$-orbital character (leaving the $M-\mathrm{Cl}$ with enhanced $p$ orbital contributions) because of the differing electronegativities of the atoms bonded to tin [i.e. isovalent hybridization (Bent, 1961)].

The $\mathrm{Sn}-\mathrm{Cl}$ bond lengths in $\mathrm{Cl}_{2} \mathrm{Sn}\left[\mathrm{Co}(\mathrm{CO})_{4}\right]_{2}$ average 2.368 (2) $\AA$, which is marginally shorter than any of the other examples in Table 3, although variations are not marked. The $\mathrm{Cl}-\mathrm{Sn}-\mathrm{Cl}$ angle in $\mathrm{Cl}_{2} \mathrm{Sn}\left[\mathrm{Co}(\mathrm{CO})_{4}\right]_{2}$ is also wider at $101.3(1)^{\circ}$ than for other $\mathrm{Cl}_{2} \mathrm{Sn}\left(M L_{n}\right)_{2}$, although all are significantly less than the tetrahedral angle. While these values are generally consistent with the isovalent hybridization ideas, there does not appear to be any correlation at the more detailed level relating trends in $\mathrm{Sn}-\mathrm{Cl}$, $\mathrm{Sn}-M$ and $\mathrm{Cl}-\mathrm{Sn}-\mathrm{Cl}$ parameters.

We thank the New Zealand Universities Grants Committee and the Petroleum Research Fund, administered by the ACS, for financial support. We are grateful to Dr W. T. Robinson, University of Canterbury, for collection of X-ray intensity data.

\section{References}

Bent, H. A. (1961). Chem. Rev. 61, 275-311.

Biryukov, B. P., Kukhtenkova, E. A., Struchkov, Yu. T., Anisimov, K. N., Kolobova, N. E. \& Khandozhkio, V. I (1971). J. Organomet. Chem. 27, 337-339.

Boer, F. P. \& FlynN, J. J. (1971). J. Am. Chem. Soc. 93, 6495-6503.

Curnow, O. J. \& Nicholson, B. K. (1984). J. Organomet. Chem. 267, 257-263.

Curnow, O. J., Nicholson, B. K. \& Severinsen, M. J. (1990). J. Organomet. Chem. 388, 379-390.

International Tables for X-ray Crystallography (1974). Vol. IV. Birmingham: Kynoch Press. (Present distributor Kluwer Academic Publishers, Dordrecht.)

MaCKAy, K. M. \& Nicholson, B. K. (1982). In Comprehensive Organometallic Chemistry, edited by G. WILKInSON, E. ABEL \& F. G. A. Stone, Ch. 43. Oxford: Pergamon Press.

O'ConnoR, J. E. \& COREY, E. R. (1967). Inorg. Chem. 6, 968-971. Patmore, D. J. \& Graham, W. A. G. (1966). Inorg. Chem. 5, 1405-1410.

Preut, H., Wolfes, W. \& Haupt, H. J. (1975). Z. Anorg. Allg. Chem. 412, 121-128.

SHELDRICK, G. M. (1976). SHELX76. Program for crystal structure determination. Univ. of Cambridge, England.

SHELDRICK, G. M. (1986). SHELXS86. Program for the solution of crystal structures. Univ. of Göttingen, Federal Republic of Germany.

STEPHENS, F. S. (1975). J. Chem. Soc. Dalton Trans. pp. 230-232.

Zubieta, J. A. \& Zuckerman, J. J. (1978). Prog. Inorg. Chem. 24, $251-475$.

Acta Cryst. (1990). C46, 1761-1763

\title{
On the Structure of 'Potassium Nitroprusside 0.8 Hydrate'
}

\author{
BY RICHARD E. MARSH* \\ A. A. Noyes Laboratory of Chemical Physics, California Institute of Technology, Pasadena, \\ California 91125, USA
}

(Received 18 October 1989; accepted 3 January 1990)

\begin{abstract}
The crystal structure of the compound reported as $\mathrm{K}_{2}\left[\mathrm{Fe}(\mathrm{CN})_{5} \mathrm{NO}\right] .0 \cdot 8 \mathrm{H}_{2} \mathrm{O}$, potassium

* Contribution No. 8351 from the A. A. Noyes Laboratory.
\end{abstract}

0108-2701/90/101761-03\$03.00 pentacyanonitrosylferrate hydrate $(1 / 0 \cdot 8)$, recently described and refined in the non-centrosymmetric space group Pna2 ${ }_{1}$ [orthorhombic; $a=30.000$ (8), $b$ $=11.272(3), c=16.053$ (4) $\AA, Z=20$; Castellano, (C) 1990 International Union of Crystallography 
Rivero, Piro \& Amalvy (1989). Acta Cryst. C45, 1207-1210], is properly described as centrosymmetric, space group Pnma. Refinement in Pnma shows that one of the $\mathrm{K}$ atoms is, instead, an $\mathrm{Na}$ atom and that three of the sites of the water molecules are partially occupied; the proper formulation of the compound is $\mathrm{K}_{9} \mathrm{Na}\left[\mathrm{Fe}(\mathrm{CN})_{5} \mathrm{NO}\right]_{5} \cdot n \mathrm{H}_{2} \mathrm{O}(n \approx 4 \cdot 8)$.

Introduction. Crystal structure analyses of the $2 \cdot 5$ and 0.8 hydrates of potassium nitroprusside, $\mathrm{K}_{2}\left[\mathrm{Fe}(\mathrm{CN})_{5} \mathrm{NO}\right]$, were recently reported (Castellano, Rivero, Piro \& Amalvy, 1989; hereafter CRPA). The structure of the 0.8 hydrate was described and refined in the non-centrosymmetric space group $P n a 2_{1}$, to an $R$ of 0.059 for 3436 reflections with $I \geq$ $3 \sigma(I)$. Surprising features of the resulting structure included (i) a relatively large spread of chemically equivalent bond lengths; for example, the $\mathrm{Fe}-\mathrm{C}$ distances ranged from 1.85 (1) to 2.01 (1) $\AA$ and $\mathrm{C}-\mathrm{N}$ from 1.07 (2) to 1.23 (2) $\AA$; (ii) peculiar coordination about $\mathrm{K}(9)$; whereas all the $\mathrm{N} \cdots \mathrm{K}$ distances about the other potassium ions were 2.71 (1) $\AA$ or greater, $K(9)$ had five $N$ neighbors between 2.36 and $2.52 \AA$. From inspection of the atomic coordinates (CRPA, Table 3), it appeared that all atoms except the water oxygen $\mathrm{O}(W 1)$ either lay close to a mirror plane at $z=0 \cdot 25$ (or 0.75 ) or were related to an equivalent atom on the opposite side of such a plane; $\mathrm{O}(W 1)$ had no such mate, but its anomalously small $B_{\text {iso }}$ value, $1.6(1) \AA^{2}$, suggested that it might want one. An attempt to refine the structure again, in space group Pnam (here described in the conventional setting, Pnma), seemed appropriate, and was successful.

Experimental. The $F_{\text {obs }}$ values were recovered from SUP 51807. Atomic coordinates were transformed and symmetrized so as to conform to Pnma; the necessary shifts were, in general, $0 \cdot 1 \AA$ or less. After preliminary least-squares refinement, a difference map showed a number of important features, including a large negative region in the vicinity of $K(9)$, smaller negative regions at two of the water molecules $[\mathrm{O}(W 1)$ and $\mathrm{O}(W 3)]$, and a positive peak in an otherwise empty region of the structure. An additional $\mathrm{O}$ atom, $\mathrm{O}(W 5)$, with a refinable population parameter, was introduced at this latter site; population parameters were added for $\mathrm{O}(W 1)$ and $\mathrm{O}(W 3)$, and the atom at $\mathrm{K}(9)$ was assigned as $\mathrm{Na}$ rather than $\mathrm{K}$ (as also indicated by its coordination distances; see above). Full-matrix refinement with all atoms anisotropic except for the added water $\mathrm{O}$ atom $\mathrm{O}(W 5)$ then proceeded routinely to a final $R$ of 0.039 for the 3436 reflections and 395 parameters [including one for extinction; final value $1.35(1) \times 10^{-6}$ ] By comparison, the final $R$ for the $P$ na $2_{1}$ model (CRPA) was 0.059 for, apparently, 392 parameters (only $\mathrm{Fe}$ and $\mathrm{K}$ atoms were treated anisotropically). Included in SUP 51807 were $F$ values for 1637 reflections with $I<3 \sigma(I)$, which were not in the refinement; for them, $R(P n m a)$ was 0.44 and $R\left(P n a 2_{1}\right)$ was 0.49 . The final Pnma coordinates are given in Table $1 .^{*}$

Refinement was by full-matrix minimization of the quantity $\sum w\left(F_{\text {obs }}^{2}-F_{\text {cal }}^{2}\right)^{2}$, with weights $w$ according to Hughes (1941) (see also Marsh \& Schomaker, 1979). Values of $\sigma\left(F_{\text {obs }}\right)$ were included in SUP 51807, but usually to only one digit which was occasionally 0 . In the final cycle the maximum shift was 0.13 e.s.d.'s. A final difference map showed excursions up to $0.66 \mathrm{e} \AA^{-3}$; peaks were present in regions appropriate for the $\mathrm{H}$ atoms of the water molecules, but were marginally competitive with other features and were ignored (as in CRPA). At the conclusion of the refinement, an additional least-squares calculation was carried out with one additional parameter, representing the fraction of $\mathrm{K}$ that might occupy the site of $\mathrm{Na}$. This parameter came out at 0.0 , indicating no disorder at this site.

Discussion. With the replacement of one $\mathrm{K}$ atom by $\mathrm{Na}$, the addition of $\mathrm{O}(W 5)$ and of the mirror-related mate of $\mathrm{O}(W 1)$, and the adjustment of the occupancy factors for $\mathrm{O}(W 1), \mathrm{O}(W 3)$ and $\mathrm{O}(W 5)$, the formulation of the compound becomes $\mathrm{K}_{9} \mathrm{Na}[\mathrm{Fe}-$ $(\mathrm{CN})_{5} \mathrm{NO}_{5} \cdot n \mathrm{H}_{2} \mathrm{O}(n \simeq 4 \cdot 8)$; there are four such units per cell. Assuming that the sites of $\mathrm{O}(W 2)$ and $\mathrm{O}(W 4)$ are fully occupied (and there is no indication to the contrary in either the difference map or the $U_{i j}^{\prime}$ 's), the amount of water in this formulation is 4.79 (4) rather than the 4.0 that would correspond to the composition presumed earlier (CRPA), $\mathrm{K}_{2}\left[\mathrm{Fe}(\mathrm{CN})_{5} \mathrm{NO}\right] \cdot 0 \cdot 8 \mathrm{H}_{2} \mathrm{O}(Z=20)$. The revised value of $D_{x}$ is $1.886 \mathrm{~g} \mathrm{~cm}^{-3}$. The compound was obtained commercially and purified by repeated recrystallization (CRPA); apparently $\mathrm{Na}$ was present in the original material and the recrystallization, while leading to a 'pure' compound, did not lead to a simple one. Loss of water from the sites of $\mathrm{O}(W 1)$, $\mathrm{O}(W 3)$ and $\mathrm{O}(W 5)$ presumably occurred later. If all these sites were fully occupied, there would be 6.0 water molecules per formula unit.

General features of the structure are as discussed by CRPA. Each of the eight independent $\mathrm{K}$ atoms is surrounded by between five and eight $\mathrm{N}$ atoms or water molecules at distances below $3 \cdot 2 \AA ; \mathrm{Na}(9)$ has six $\mathrm{N}$ neighbors at shorter distances.

As CRPA pointed out, the water molecules do not form strong hydrogen bonds; however, each of them

\footnotetext{
* A table of $U_{i j}$ 's has been deposited with the British Library Document Supply Centre as Supplementary Publication No. SUP 52924 (3 pp.). Copies may be obtained through The Technical Editor, International Union of Crystallography, 5 Abbey Square, Chester CH1 2HU, England.
} 
Table 1. Coordinates $\left(\times 10^{4}\right)$ and temperature factors $\left(\AA^{2} \times 10^{4}\right)$, space group Pnma $(a=30 \cdot 000, \quad b=$

$$
16 \cdot 053, c=11 \cdot 272 \AA)
$$

$$
U_{\mathrm{eq}}=(1 / 3) \sum_{i} \sum_{j} U_{i j} a_{i}^{*} a_{j}^{*} \mathbf{a}_{i} \cdot \mathbf{a}_{j}
$$

\begin{tabular}{|c|c|c|c|c|}
\hline & $x$ & $y$ & $z$ & $U_{e q}$ or $B$ \\
\hline $\mathrm{Fe}(1)$ & $1165.0(2)$ & $158.0(4)$ & $176.0(6)$ & $195(1)$ \\
\hline $\mathrm{Fe}(2)$ & $1181.0(2)$ & $-23.0(4)$ & $5113.0(6)$ & $193(1)$ \\
\hline $\mathrm{Fe}(5)$ & $2436 \cdot 0(3)$ & 7500 & $214.0(9)$ & $230(2)$ \\
\hline$N(1)$ & $1405(1)$ & $-421(3)$ & $1192(4)$ & $235(9)$ \\
\hline$O(1)$ & $1582(1)$ & $-846(3)$ & 1819 (4) & $422(10)$ \\
\hline C(11) & $841(2)$ & $930(3)$ & $1173(5)$ & 229 (11) \\
\hline $\mathrm{N}(11)$ & $638(2)$ & $1406(3)$ & $1693(4)$ & $320(10)$ \\
\hline$C(12)$ & $640(2)$ & $-542(3)$ & $84(5)$ & $242(10)$ \\
\hline$N(12)$ & $330(2)$ & $-957(3)$ & $50(5)$ & $415(11)$ \\
\hline$C(13)$ & $1438(2)$ & $-506(3)$ & $-1036(4)$ & $241(11)$ \\
\hline$N(13)$ & $1590(2)$ & $-931(3)$ & $-1731(4)$ & $395(12)$ \\
\hline$C(14)$ & $1647(2)$ & $970(3)$ & $156(5)$ & 253 (11) \\
\hline$N(14)$ & $1925(1)$ & $1453(3)$ & 233 (4) & 344 (11) \\
\hline$C(15)$ & $895(2)$ & 794 (4) & $-1067(5)$ & $275(12)$ \\
\hline$N(15)$ & $720(2)$ & $1180(3)$ & $-1776(4)$ & $405(12)$ \\
\hline $\mathrm{N}(2)$ & $1436(1)$ & $516(3)$ & $6134(4)$ & $228(9)$ \\
\hline $\mathrm{O}(2)$ & $1617(1)$ & 879 (3) & $6835(4)$ & $387(10)$ \\
\hline$C(21)$ & $700(2)$ & $771(3)$ & $4916(5)$ & $308(12)$ \\
\hline$N(21)$ & $425(2)$ & $1264(3)$ & $4797(5)$ & $508(13)$ \\
\hline$C(22)$ & $1497(2)$ & $524(3)$ & $3871(5)$ & $223(11)$ \\
\hline$N(22)$ & $1677(2)$ & $855(3)$ & $3126(4)$ & 338 (11) \\
\hline$C(23)$ & $1618(2)$ & $-922(3)$ & $5146(4)$ & 235 (11) \\
\hline $\mathrm{N}(23)$ & $1876(1)$ & $-1440(3)$ & $5244(4)$ & $321(10)$ \\
\hline$C(24)$ & $811(2)$ & $-662(3)$ & $6152(5)$ & $262(12)$ \\
\hline $\mathrm{N}(24)$ & $590(2)$ & -1060 & $6751(4)$ & $413(12)$ \\
\hline$C(25)$ & $884(2)$ & $-655(3)$ & $3908(5)$ & $271(12)$ \\
\hline $\mathrm{N}(25)$ & $694(2)$ & $-1026(3)$ & $3217(4)$ & $383(12)$ \\
\hline $\mathrm{N}(5)$ & $1876(2)$ & 7500 & $228(6)$ & $305(15)$ \\
\hline$O(5)$ & $1492(2)$ & 7500 & $251(7)$ & $600(20)$ \\
\hline$C(51)$ & $2476(3)$ & 7500 & $1884(7)$ & $308(18)$ \\
\hline$N(51)$ & 2496 (3) & 7500 & $2869(6)$ & $464(20)$ \\
\hline$C(52)$ & $2483(2)$ & 6307 (3) & $260(4)$ & $263(10)$ \\
\hline $\mathrm{N}(52)$ & 2497 (2) & 5591 (3) & 334 (4) & $407(11)$ \\
\hline$C(53)$ & $2476(3)$ & 7500 & $-1469(7)$ & $264(17)$ \\
\hline$N(53)$ & $2482(2)$ & 7500 & $-2457(6)$ & $318(15)$ \\
\hline$C(55)$ & $3088(2)$ & 7500 & $232(7)$ & $234(15)$ \\
\hline$N(55)$ & $3467(2)$ & 7500 & $262(7)$ & $421(18)$ \\
\hline $\mathrm{O}(W 1)^{*}$ & 2497 (2) & $607(3)$ & $8242(5)$ & $619(16)$ \\
\hline$O(W 2)$ & $593(2)$ & 7500 & $-1387(6)$ & $503(16)$ \\
\hline$O(W 3)^{*}$ & $701(3)$ & 7500 & $-4926(8)$ & $698(30)$ \\
\hline$O(W 4)$ & $-196(2)$ & 2500 & $-2350(6)$ & $578(17)$ \\
\hline$K(1)$ & $2535.0(4)$ & $4283.0(8)$ & 2067 (1) & $431(3)$ \\
\hline$K(2)$ & $22 \cdot 0(6)$ & 2500 & $3291(2)$ & $369(4)$ \\
\hline$K(4)$ & $231.0(7)$ & 2500 & $-224(2)$ & $422(4)$ \\
\hline$K(5)$ & $1350.0(7)$ & 7500 & $6994(2)$ & $483(5)$ \\
\hline$K(6)$ & $1473.0(7)$ & 2500 & $2402(2)$ & $473(5)$ \\
\hline$K(7)$ & $686.0(7)$ & 2500 & $6508(2)$ & $415(4)$ \\
\hline $\mathrm{K}(8)$ & $15 \cdot 0(5)$ & $5015 \cdot 0(9)$ & $2263(1)$ & $473(3)$ \\
\hline $\mathrm{Na}(9)$ & $2527.0(9)$ & 2500 & $-19(3)$ & $267(6)$ \\
\hline $\mathrm{O}(W 5)^{*}$ & $1356(9)$ & 2500 & $8259(25)$ & $7 \cdot 1(10)$ \\
\hline
\end{tabular}

* Population factors: $\mathrm{O}(W 1), 0.84(1) ; \mathrm{O}(W 3), 0.79(2) ; \mathrm{O}(W 5), 0.32$ (2). $\dagger$ Isotropic displacement parameter, $B$.

has just two $\mathrm{N}$ neighbors closer than $3 \cdot 1 \AA$. The added water molecule $\mathrm{O}(W 5)$ is coordinated to a single $\mathrm{K}$ atom, which may account for its low occupancy factor. $\mathrm{O}(W 1)$ also has but a single $\mathrm{K}$ neighbor, at the very short distance of 2.506 (6) $\AA$; the other waters have at least two neighbors.
Table 2. Bond lengths $(\AA)$ within the anions

$\begin{array}{ll}\mathrm{Fe}(1)-\mathrm{N}(1) & 1.641(4) \\ \mathrm{Fe}(1)-\mathrm{C}(11) & 1.936(5) \\ \mathrm{Fe}(1)-\mathrm{C}(12) & 1.936(5) \\ \mathrm{Fe}(1)-\mathrm{C}(13) & 1.916(5) \\ \mathrm{Fe}(1)-\mathrm{C}(14) & 1.948(5) \\ \mathrm{Fe}(1)-\mathrm{C}(15) & 1.914(5) \\ \mathrm{N}(1)-\mathrm{O}(1) & 1.116(6) \\ \mathrm{C}(11)-\mathrm{N}(11) & 1.139(7) \\ \mathrm{C}(12)-\mathrm{N}(12) & 1.146(7) \\ \mathrm{C}(13)-\mathrm{N}(13) & 1.134(7) \\ \mathrm{C}(14)-\mathrm{N}(14) & 1.142(7) \\ \mathrm{C}(15)-\mathrm{N}(15) & 1.139(7) \\ \mathrm{Fe}(2)-\mathrm{N}(2) & 1.631(4) \\ \mathrm{Fe}(2)-\mathrm{C}(21) & 1.938(5) \\ \mathrm{Fe}(2)-\mathrm{C}(22) & 1.906(5) \\ \mathrm{Fe}(2)-\mathrm{C}(23) & 1.950(5) \\ \mathrm{Fe}(2)-\mathrm{C}(24) & 1.911(5)\end{array}$

$\begin{array}{ll}\mathrm{Fe}(2)-\mathrm{C}(25) & 1.915(5) \\ \mathrm{N}(2)-\mathrm{O}(2) & 1.120(6) \\ \mathrm{C}(21)-\mathrm{N}(21) & 1.151(7) \\ \mathrm{C}(22)-\mathrm{N}(22) & 1.130(7) \\ \mathrm{C}(23)-\mathrm{N}(23) & 1.142(7) \\ \mathrm{C}(24)-\mathrm{N}(24) & 1.144(7) \\ \mathrm{C}(25)-\mathrm{N}(25) & 1.135(7) \\ \mathrm{Fe}(5)-\mathrm{N}(5) & 1.678(7) \\ \mathrm{Fe}(5)-\mathrm{C}(51) & 1.887(8) \\ \mathrm{Fe}(5)-\mathrm{C}(52) & 1.921(5) \\ \mathrm{Fe}(5)-\mathrm{C}(53) & 1.901(8) \\ \mathrm{Fe}(5)-\mathrm{C}(55) & 1.956(7) \\ \mathrm{N}(5)-\mathrm{O}(5) & 1.153(9) \\ \mathrm{C}(51)-\mathrm{N}(51) & 1.112(11) \\ \mathrm{C}(52)-\mathrm{N}(52) & 1.154(7) \\ \mathrm{C}(53)-\mathrm{N}(53) & 1.114(10) \\ \mathrm{C}(55)-\mathrm{N}(55) & 1.137(10)\end{array}$

Bond lengths within the $\mathrm{Fe}(\mathrm{CN})_{5} \mathrm{NO}$ anions are more uniform than in the earlier description: $\mathrm{Fe}-\mathrm{N}$ range from 1.641 (4) to 1.678 (7) $\AA, \mathrm{Fe}-\mathrm{C}$ from $1.887(8)$ to $1.956(7) \AA, \mathrm{N}-\mathrm{O}$ from $1.116(6)$ to $1 \cdot 153(9) \AA$ and $\mathrm{C}-\mathrm{N}$ from $1 \cdot 112(11)$ to $1 \cdot 154$ (7) $\AA$ (see Table 2). But the differences within these sets of values, while small, are surely significant. The largest spread of values is within the anion involving Fe(5), which lies on a mirror plane. Similar distortions were noted by Amalvy, Varetti, Aymonino, Castellano, Piro \& Punte (1986) in the 1.25 hydrate of $\mathrm{K}_{2} \mathrm{Fe}(\mathrm{CN})_{5} \mathrm{NO}$, which crystallizes with four $\mathrm{Fe}(\mathrm{CN})_{5} \mathrm{NO}$ groups per asymmetric unit and for which the IR spectrum showed four distinct $\mathrm{N}-\mathrm{O}$ frequencies. (The precision of the X-ray diffraction analysis of that compound was not sufficient to permit correlation of the bond lengths with the frequencies.) It seems clear that 'lattice effects' - the specifics of cation coordination and hydrogen bonding - can lead to appreciable rehybridization within the $\mathrm{Fe}(\mathrm{CN})_{5} \mathrm{NO}$ anions, as suggested by Amalvy et al. (1986).

\section{References}

Amalvy, J. I., Varetti, E. L., Aymonino, P. J., Castellano, E. E., Piro, O. E. \& Punte, G. (1986). J. Crystallogr. Spectrosc. Res. 16, 537-555.

Castellano, E. E., Rivero, B. E., Piro, O. E. \& Amalvy, J. I. (1989). Acta Cryst. C45, 1207-1210.

Hughes, E. W. (1941). J. Am. Chem. Soc. 63, 1737-1752.

MARSH, R. E. \& SCHOMAKER, V. (1979). Inorg. Chem. 18, 23312336. 